TERAKREDITASI Berdasarkan SK Dirjen Dikti Depdiknas Nomor: 65a/DIKTl/Kep/2008

MENIMBANG KOMPATIBELITAS MULTIKULTURALISME DAN ISLAM: IKHTIAR MENGGAGAS PENDIDIKAN ISLAM MULTIKULTURAL DI INDONESIA Mukhlis

ASESMEN AKHLAK MULIA: Suatu Model Alternatif Penilaian Pembelajaran Agama Siti Muri'ah

MENILAI Ulang GAGASAN NEGARA KHILÂFAH ABÛ AL-A'LÂ AL-MAUDÛDî Arsyad Sobby Kesuma

AL-A'IMMAH MIN QURAISY: ANTARA DOKTRIN DAN KEBUTUHAN SOSIAL Ahwan Mukarrom

SISTEM KALENDER ISLAM DALAM PERSPEKTIF EVOLUSI SYARI'AA Abd. Salam

Desain DakWAH untuk PEMBINAan KeAgamaAn KOMUNITAS ELIT INTELEKTUAL Bukhari 


\section{PEDOMAN TRANSLITERASI}

\begin{tabular}{|c|c|c|c|}
\hline Arab & Latin & Arab & Latin \\
\hline 1 & $=$ & ف & $=\mathbf{f}$ \\
\hline ب & $=$ & ق & $=\mathrm{q}$ \\
\hline$\dot{H}$ & ts & ك & $=\mathrm{k}$ \\
\hline 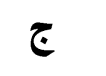 & $=$ & J & $=1$ \\
\hline$\tau$ & $=$ & r & $=\mathrm{m}$ \\
\hline$\dot{\tau}$ & $=\mathbf{k h}$ & ن & $=\mathbf{n}$ \\
\hline$د$ & $=$ & و & $=\mathbf{w}$ \\
\hline$\dot{j}$ & $\mathrm{dz}$ & ○ & $=h$ \\
\hline J & $=$ & $\varepsilon$ & $=$, \\
\hline j & $=$ & ي & $=\mathbf{y}$ \\
\hline س & $=$ & & \\
\hline ص ش & $\begin{array}{l}\text { sy } \\
\text { sh }\end{array}$ & \multicolumn{2}{|c|}{$\begin{array}{l}\text { Untuk Madd } \\
\text { dan Diftong }\end{array}$} \\
\hline ض & $=$ & $i=$ & $=\hat{a}$ (a panjang) \\
\hline$b$ & th & إين & $=\hat{\mathbf{i}}(\mathbf{i}$ panjang) \\
\hline ظ & $\mathbf{z h}$ & أوز & $=\hat{\mathbf{u}}$ (u panjang) \\
\hline$\varepsilon$ & $=$ & آوز & $=$ aw \\
\hline$\dot{\varepsilon}$ & $=\mathbf{g h}$ & = آين & $=$ ay \\
\hline
\end{tabular}




\section{ISI}

TRANSLITERASI

ARTIKEL

Mukhlis

Menimbang Kompatibelitas

Multikulturalisme dan Islam:

Ikhtiar Menggagas Pendidikan Islam

Multikultural di Indonesia • 201-224

Siti Muri'ah

Asesmen Akhlak Mulia:

Suatu Model Alternatif Penilaian

Pembelajaran Agama • 225-248

Yusuf Hanafi

Perkawinan Anak di Bawah Umur

dalam Perspektif Hukum Islam • 249-274

Arsyad Sobby Kesuma Menilai Ulang Gagasan Negara Khilâfah

Abû al-A'lâ al-Maudûdî • 275-300

Ahwan Mukarrom Al-A'immah min Quraisy:

Antara Doktrin dan Kebutuhan

Sosial • 301-322

Abd. Salam

Sistem Kalender Islam dalam Perspektif

Evolusi Syari'ah • 323-350

Bukhari

Desain Dakwah untuk Pembinaan

Keagamaan Komunitas

Elit Intelektual • 351-370

Ahmad Munir Teologi Properti:

Telaah Eksistensi dan Fungsi

Kekayaan • 371-392

BOOK REVIEW

Ahmad Fathan Aniq Discovering Indonesian Islam through Fatâwâ • 393-408

INDEKS 


\title{
ASESMEN AKHLAK MULIA: \\ SUATU MODEL ALTERNATIF PENILAIAN \\ PEMBELAJARAN AGAMA
}

\author{
Siti Muri'ah*
}

\section{Abstract}

One weakness of akhlak teaching method applied in schools is its teacher centered assessment. Teachers feel as the most well-informed sources about students' akhlak while teachers' capability of knowing students' akhlak comprehensively is limited. Teachers' chance to meet face-to-face with students is only in the learning process so that teachers' assessment can not show the real akhlak of their students. Teachers should involve other parties who often associate with students, especially their peers. In addition, assessment instrument used by the teachers should not be limited to examination only. Therefore, comprehensive akblak assessment is needed.

In this writing, I describe alternative method to assess students' akhlak. With this method, we can assess batiniyah dimensions including willingness, conscience, value and attitude and also labiriyah dimensions manifested in behaviors. This method applies self and peer assessment by involving students in inter and intra relations. Assessment instruments could be questionnaires, observation and portfolios in likert scale, semantic differential and thurstone scale.

Keywords: Pembelajaran, Asesmen, Akhlak, Model Evaluasi.

FENOMENA meluasnya perilaku remaja yang dinilai bertentangan dengan agama dan norma masyarakat dewasa ini mengundang perhatian dan keprihatinan berbagai pihak. Mereka menyuarakan

*Penulis adalah Guru Besar Sekolah Tinggi Agama Islam Negeri (STAIN) Samarinda Kaltim. e-mail: prof.muriah2008@g.mail.com 
pentingnya penekanan akhlak mulia dalam penyelenggaraan pendidikan, karena akhlak mulia dapat menjadi stabilisator bagi kehidupan bermasyarakat.

Pembinaan akhlak mulia secara esensial merupakan pembentukan watak dan perilaku terpuji peserta didik yang termanifestasi dalam kehidupan sehari-hari yang bersumber dari syara' maupun norma yang berlaku di masyarakat. Dengan memperoleh pendidikan akhlak yang memadai diharapkan dapat menangkal perilaku-perilaku menyimpang pada diri mereka.

Pelaksanaan pendidikan akhlak pada institusi pendidikan Islam tidak terlepas dari kualitas pembelajaran dan sistem penilaiannya. Sistem penilaian yang baik menurut Djemari Mardapi ${ }^{1}$ akan mendorong guru dalam menentukan strategi mengajar yang baik dan memotivasi siswa untuk belajar lebih baik. Penilaian menjadi aspek penting bagi upaya peningkatan kualitas pendidikan, karena melalui penilaian akan diperoleh informasi-informasi atas pembelajaran yang dilakukan guru dan siswa untuk dijadikan acuan pemberian feed back bagi keduanya. ${ }^{2}$

Penilaian akhlak mulia sebagai hasil dari proses pembelajaran dalam penerapannya dapat memanfaatkan keterlibatan siswa secara inter dan intra individu peserta didik. Keterlibatan peserta didik dalam penilaian akan mendorong partisipasi aktif yang bersangkutan untuk merealisasikan ketercapaian tujuan pembelajaran sekaligus membuatnya sadar posisi dalam konteks kompetensi yang harus dicapai.

Realita penerapan penilaian akhlak mulia hasil dari pembelajaran pada berbagai institusi pendidikan selama ini masih menerapkan penilaian yang parsial dan konvensional. Penilaian tersebut cenderung mengedepankan hasil akhir

${ }^{1}$ Djemari Mardapi, Pengembangan Instrument Penelitian Pendidikan (Yogyakarta: Pascasarjana UNY, 2005), 11.

2P. Black \& D. William, "Inside the Black Box: Raising Standards Through Classroom Assessment", dalam Phi Delta Kappa, 80 (2), 1998, 139148. 
pembelajaran (assessment of learning) dibanding penilaian secara berkelanjutan (assessment for learning). Selain itu praktek penilaian akhlak mulia peserta didik yang dilakukan guru lebih bersifat 'perabaan' dengan dimensi-dimensi dan instrumen yang tidak jelas sehingga menimbulkan bias. Kondisi itu memunculkan pemikiran mengenai pentingnya dikembangkan model penilaian akhlak mulia dengan menetapkan dimensi-dimensi yang jelas, instrumen yang tepat, dilakukan secara berkala dan memanfaatkan keterlibatan intra dan inter individu peserta didik.

\section{Konsep Akhlak Mulia}

Akhlak mulia menempati posisi penting dalam kehidupan manusia baik sebagai individu, anggota masyarakat maupun bangsa. Akhlak mulia menjadi salah satu indikasi kesalehan seseorang di hadapan Ilahi dan sesama sehingga seseorang yang berakhlak mulia mendapatkan sebutan dari masyarakat sebagai orang saleh karena akhlaknya tersebut.

Pemaknaan akhlak sebagaimana disebutkan di dalam alMu'jam al-Wasith, ${ }^{3}$ yakni sifat yang tertanam dalam jiwa yang melahirkan macam-macam perbuatan baik atau buruk tanpa membutuhkan pemikiran dan pertimbangan. Demikian halnya al-Ghazâlî̀ menyebut akhlak sebagai sifat yang tertanam dalam jiwa yang menimbulkan macam-macam perbuatan dengan mudah tanpa memerlukan pemikiran dan pertimbangan.

Pendapat tersebut menggambarkan adanya keterkaitan aspek batiniyah dan lahiriyah dalam akhlak, sedangkan perbuatan tanpa memerlukan pemikiran dan pertimbangan sebagaimana dimaksud dapat dimaknai perbuatan yang dilakukan seseorang secara wajar berdasarkan kondisi jiwanya, bukan perbuatan yang dibuat-buat (rekayasa). Hal ini diperkuat dengan pendapat

3Ibrahîm Anîs, Al-Mu'jam al-Wasîth (Mesir: Dâr Mâ'arif, 1972), 202.

"Al-Ghazâlî, I hyyâ' 'Ulûm al-Dîn, Jilid III (Kairo: al-Masyhad al-Husayn, t.t.), 56 . 
A $\underline{\text { hmad Amîn }}{ }^{5}$ yang memberi penekanan akhlak pada kehendak yang dibiasakan sehingga suatu perbuatan yang didasarkan atas kehendak seseorang untuk melakukannya secara berulang dapat dikategorikan sebagai akhlak.

Konsepsi akhlak berdasarkan beberapa sumber di atas tampak memiliki kesamaan penekanan pada keadaan jiwa seseorang yang dapat merefleksikan perbuatan secara wajar tanpa rekayasa. Dengan demikian dapat disimpulkan, bahwa akhlak adalah kondisi internal jiwa seseorang yang dapat melahirkan perbuatan tertentu yang dilakukan secara wajar tidak direkayasa, berpotensi untuk dilakukan secara berulang kali, didasari oleh kesadaran dan kehendak diri yang bersangkutan.

\section{Tolok Ukur Penilaian Akhlak Mulia}

Akhlak mulia (akhlâq al-karîmah) adalah model-model perilaku atau tindakan yang memiliki nilai kebajikan dan menjadi ukuran untuk menentukan suatu tindakan dinyatakan benar atau salah berdasarkan norma Islam. ${ }^{6}$ Norma-norma Islam menurut Zulkabir $^{7}$ diwujudkan dalam bentuk perintah-larangan, dorongan-cegahan, dan pujian-kecaman. Tindakan yang baik dan benar adalah segala hal yang diperintahkan, didorongkan, dipuji dan diharapkan oleh Islam untuk dilakukan, sebaliknya tindakan yang dikecam dan dilarang dikategorikan sebagai tindakan tercela. Asmaran ${ }^{8}$ juga menegaskan bahwa akhlak mulia adalah sifat-sifat dan perilaku yang sesuai dengan norma-norma atau ajaran Islam secara lahiriyah dan batiniyah. Akhlak mulia secara lahiriyah merujuk pada perilaku terpuji yang tampak, sedangkan

${ }^{5}$ Ahmad Amîn, Kitâb al-Akhlâq (Kairo: Dâr al-Kutub al-Mishriyyah, 1974), 63.

'Aep Saefudin , "Akhlak dalam Perspektif Wacana Pemikir Muslim", dalam Jurnal Ta'dib, (2), 1, 2002, 70.

7Zulkabir dkk., Islam Konseptual dan Kontekstual (Bandung: Itqan, 1993), 98.

${ }^{8}$ Asmaran As, Pengantar Studi Akblak (Jakarta: Rajawali, 2002), 207. 
akhlak mulia secara batiniyah merujuk pada sifat-sifat terpuji dalam jiwa. Jadi, akhlak mulia pada hakekatnya adalah kondisi jiwa dan perilaku terpuji berdasarkan norma-norma Islam.

Perbuatan seseorang dalam konteks akhlak mulia ini memerlukan tolok ukur penilaian. Dinyatakan al-Ghazâlî bahwa berakhlak mulia berarti menghilangkan semua kebiasaan tercela yang sudah dirincikan oleh agama Islam serta menjauhkan diri dari padanya. Suatu perbuatan dapat dikatakan sebagai akhlak mulia apabila menimbulkan kerelaan seluruh makhluk dan sebagai tolok ukur untuk menentukan baik-buruknya perbuatan akhlak adalah syara' dan akal sehat (ijtihad). Oleh karena itu, suatu perbuatan terpuji yang didasarkan syara' dan akal sehat dapat dinamakan akhlak mulia. ${ }^{9}$ Tolok ukur penilaian akhlak mulia berdasarkan syara' juga dijadikan pedoman Umary ${ }^{10}$ sebagaimana penegasannya bahwa akhlak mulia (akblâq alkarimah) itu akhlak yang baik dan benar berdasarkan syara' sebaliknya akhlak tercela (akhlâq al-madそmûmab) adalah akhlak yang tidak baik dan tidak benar berdasarkan syara'.

Selanjutnya peran akal sehat dalam penilaian akhlak, yakni untuk mempertimbangkan baik buruknya suatu perbuatan yang dilakukan seseorang. Seruan penggunaan akal secara nyata dapat dilihat dalam al-Qur'an dengan ungkapan kata un₹̧urû (Qs. 6:11, 3:137, 16:36), afalâ táqilûn (Qs. 2:44, 76, 3:65, 6:32, 7:169, 10:16), la'allakum ta'qilûn (Qs. 2:242, 6:151, 12:2), dan kalimat inkuntum táqilûn (Qs. 3:118, 26:28, 40:67).

\section{Dimensi-Dimensi Penilaian Akhlak Mulia}

Akhlak sebagaimana telah diuraikan sebelumnya merupakan kondisi kejiwaan seseorang yang merefleksikan perbuatan tertentu secara wajar tanpa adanya rekayasa. Akhlak itu terlahir

${ }^{9}$ M. J. al-Qasimi, Mau'iz̧hah al- Mu'minîn, Jilid II (Kairo: Dâr al-'Usûr li al-Thaba' wa al-Nasyr, 1969), 194.

${ }^{10}$ B. Umary, Materi Akblak (Solo: Ramadhani, 1993), 196. 
dari dalam jiwa seseorang yang selanjutnya menggerakkan perbuatan-perbuatan terpuji ataupun tercela. Perbuatan manusia itu menurut Asmaran ${ }^{11}$ merupakan manifestasi dari kondisi batinnya. Akhlak mulia sebagai manifestasi kondisi batin terpuji, sebaliknya akhlak tercela sebagai manifestasi dari kondisi batin yang tidak terpuji. Dengan demikian, akhlak mulia seseorang dalam wujud perbuatan nyata (lahiriah) memiliki keterkaitan erat dengan kondisi jiwanya (batiniah).

Akhlak mulia terefleksi pula dari kualitas keimanan seseorang karena keimanan berfungsi sebagai kekuatan spiritual untuk membangkitkan motivasi agar seseorang meyakini bahwa melakukan perbuatan terpuji itu memiliki kebaikan. Dalam kaitan ini, ibadah berfungsi sebagai pembersih jiwa dan perasaan seseorang sehingga dirinya merasa ringan untuk memilih segala hal yang baik, dan muamalah berfungsi sebagai penata tatanan sosial di mana seseorang berada. Penetapan akhlak mulia tidak hanya dilihat dari eksistensinya (perbuatan lahiriah), tetapi juga dilihat dari esensinya (kondisi batin) yang mendorong dan menentukan perbuatan lahiriyah seseorang. Perbuatan lahiriyah sebenarnya digerakkan oleh sifat yang terpendam dalam jiwa. Oleh karena itu, al-Ghazâlî12 menyatakan agar dalam menilai akhlak seseorang tidak hanya melihat perbuatan yang tampak tetapi juga perlu dinilai dari batinnya.

Berdasarkan uraian di atas berarti perilaku lahiriyah seseorang itu merupakan manifestasi dari keadaan jiwanya. Kondisi jiwa dalam diri seseorang menjadi dasar lahirnya berbagai perilaku nyata dalam kehidupan sehari-hari. Kondisi jiwa yang dihiasi oleh sifat-sifat mulia akan merefleksikan beragam perilaku mulia, demikian pula halnya kondisi jiwa yang dihiasi oleh sifat-sifat tercela juga akan merefleksikan perilaku tercela. Dengan demikian, akhlak mulia itu mencakup kondisi

${ }^{11}$ Asmaran, Pengantar Studi ...., 208.

${ }^{12} \mathrm{Al}-\mathrm{Ghazâlî,} \mathrm{Al-Arba'în} \mathrm{fî̀} \mathrm{Ushûl} \mathrm{al-Dîn} \mathrm{(Kairo:} \mathrm{Maktabah} \mathrm{al-Jindi,} \mathrm{t.t.),}$ 19. 
jiwa (affective) dan perilaku nyata (behaviour). Dimensi-dimensi karakteristik afektif akhlak meliputi kehendak (willingness), kata hati (conscience), ${ }^{13}$ sikap (attitude), dan nilai (value) ${ }^{14}$ sehingga penilaian akhlak mulia juga harus mengacu pada dimensidimensi tersebut.

\section{Kehendak (Willingness)}

Kehendak merupakan keinginan yang kuat (niat) untuk melakukan ataupun menghindari suatu perbuatan. Kehendak menjadi daya penggerak yang dapat menimbulkan perbuatan. Hampshire ${ }^{15}$ menegaskan bahwa kehendak itu menggerakkan seseorang untuk mencapai sesuatu. Menghendaki berarti menyusun nilai, sumber daya dan energi dengan pemahaman pribadi yang cukup untuk menggerakkan diri menuju ke suatu sasaran.

Setiap perilaku manusia lahir dari kehendaknya dan setiap kehendak lahir dari keyakinan yang tertanam dalam jiwanya. ${ }^{16}$ Hal ini berarti perilaku seseorang yang dapat dinilai adalah perilaku yang lahir dari suatu kehendak karena dalam kenyataannya terdapat perilaku yang tidak disengaja. Menurut Amîn, ${ }^{17}$ bahwa kecerdasan, kekuatan akal, keterampilan, dan luasnya pengetahuan yang dimiliki seseorang tidak akan mempengaruhi kehidupannya bila tidak didorong oleh kekuatan kehendak yang menimbulkan perbuatan. Kehendak baik menurutnya itu bila berubah menjadi perbuatan, maka perbuatan 80.

${ }^{13}$ Ahmad Amîn, Etika (Ilmu Akblak) (Jakarta: Bulan Bintang, 1995), 61-

${ }^{14} \mathrm{~L} . \mathrm{W}$. Anderson, Assessing Affective Characteristics in the Schools (Boston: Allyn \& Bacon, Inc. 1981), 32-35; Mardapi, Pengembangan ..., 63-4; Gable R. K., Instrument Development in the Affective Domain (Boston: Kliwer Nijhoff Publishing, 1986), 2.

15S. Hampshire, Freedom of Individual (New York: Harper, 1966), 16.

${ }^{16}$ B. F. Skinner, About Behaviorism (New York: Vintage Books, 1976), 11.

${ }^{17}$ Amîn, Kitâb ..., 61. 
tersebut dikategorikan baik. Perbuatan baik tidak dinilai hanya dari tampilannya, namun juga dinilai dari kehendak yang menimbulkannya sehingga tidak terdapat perbuatan baik tanpa kehendak baik.

Penilaian terhadap baik-buruknya suatu perilaku menurut Asmaran ${ }^{18}$ menyertakan kehendak (niat) sebagai aspek penilaian. Kehendak adalah sesuatu yang mendorong jiwa seseorang, memberi alasan, dan dasar seseorang melakukan sesuatu. Kehendak merupakan unsur yang menentukan arah pilihan dari kecenderungan hati. Pendapat senada dikemukakan Amîn, ${ }^{19}$ bahwa hukum akhlak memberi penilaian suatu perilaku baik dan buruk menurut niatnya. Oleh sebab itu, manusia tidak tercela atas perbuatan yang dia lakukan dengan niat baik meskipun buruk akibatnya, tetapi ia tercela bila ia sanggup menyelidiki sebelumnya akibat perbuatan tersebut. Pentingnya niat sebagai aspek penilaian perbuatan seseorang ditegaskan Rasulullah saw. dalam sebuah hadis yang artinya: "Segala perbuatan selalu mempunyai niat, dan perbuatan itu dinilai sesuai niatnya" (H. R. Bukhari-Muslim).

Kehendak sebagaimana diuraikan di atas dapat mendorong kekuatan seseorang untuk berbuat sesuatu ataupun mencegah kekuatan dimaksud. Dorongan kekuatan dalam akhlak secara normatif diarahkan pada terwujudnya perbuatan-perbuatan terpuji berdasarkan syara', sedangkan pencegahannya dilakukan terhadap perbuatan-perbuatan tercela.

\section{Kata Hati (Conscience).}

Setiap manusia diciptakan Allah dalam keadaan fitrah (Qs. alRûm [30]:30). Fitrah merupakan hidayah yang diberikan Allah kepada manusia, yaitu kejadian asalnya yang suci dan baik. ${ }^{20}$

${ }^{18}$ Asmaran, Pengantar Studi ..., 36-8.

${ }^{19}$ Amîn, Kitâb ..., 137.

${ }^{20} \mathrm{Al}-\mathrm{Ghazâl} \hat{1}$, Ibyyâ' .... 31. 
Berdasarkan fitrah tersebut manusia menjadi makhluk yang $\underline{h} a n \hat{i} f$, yakni secara alami memiliki kecenderungan terhadap hal-hal yang benar, baik, dan yang suci. Manusia dalam jiwanya merasa ada kekuatan yang mewajibkannya untuk berbuat kebaikan dan menjauhi kejahatan. Bila dia berbuat baik akan merasakan ketenangan karena sesuai dengan bisikan jiwanya, sebaliknya jika ia melakukan kesalahan akan merasakan tersiksa jiwanya.

Penciptaan yang fitrah tersebut menjadikan setiap orang merasa dalam jiwanya terdapat pertentangan, merasa berdosa, dan menyesal ketika melakukan perbuatan tidak terpuji. Sebaliknya, seseorang merasa gembira dan bersyukur ketika mampu menghalau kekuatan yang mengarahkan pada tindakan tidak terpuji tersebut. Kekuatan ini menurut Amîn ${ }^{21}$ disebut sebagai "kata hati" yang mendahului perbuatan, mengiringi, dan menyusulnya.

Kata hati mendahului perbuatan dengan memberi petunjuk akan perbuatan wajib dan menakutinya dari kemaksiatan, mengiringinya untuk menyempurnakan perbuatan yang baik dan menahan dari perbuatan yang buruk, dan menyusulnya dengan perasaan senang ketika ditaati dan merasa salah ketika perbuatan dilanggarnya. Kata hati yang timbul seolah memerintahkan diri seseorang agar melakukan kewajiban dan memperingatkan kepadanya agar jangan sampai menyalahinya. Kata hati menurut al-A $\underline{\text { hwanît }} \hat{1}^{22}$ memantulkan bermacam-macam perilaku dan juga menilai baik-buruknya suatu perbuatan. Kata hati dapat membimbing manusia untuk berbuat baik dan menjauhkannya dari perbuatan buruk.

Lebih lanjut dikemukakan Amîn'3 bahwa dalam batin manusia itu terdapat rasa was-was (temptation) dan kata hati yang masing-masing merupakan kecenderungan yang tertekan karena

${ }^{21}$ Amîn, Kitâb ..., 80. 102.

22A. F. al-Ahwânî, Al-Tarbiyyah fì al-Islâm (Kairo: Dâr al-Ma'ârif, t.t.),

${ }^{23}$ Amîn, Kitâb ..., 81 
adanya keinginan baik dan keinginan buruk pada diri manusia. Bila keinginan buruk ditekan menimbulkan rasa was-was dan bujukan yang mengajak kearah keburukan, sebaliknya bila keinginan baik ditekan terdengar kata hati, menderita karena keburukan dan memanggil berbuat baik. Jadi, rasa was-was itu adalah keburukan yang menguasai kebaikan, dan kata hati merupakan suara kebaikan yang menguasai keburukan.

Perintah dan larangan kata hati intensitasnya berbeda pada setiap individu. Terkadang seseorang merasakan penyesalan mendalam dari kata hati atas perbuatannya, sementara orang lain tidak merasa adanya sesuatu yang buruk, namun sebaik-baik orang itu kuat perasaan kata hatinya. Perasaan kata hati ini menjadi watak dasar manusia sedangkan pendidikan menjadi faktor yang turut membentuknya.

\section{Sikap (Attitude)}

Sikap adalah konstruk yang terdiri atas respons afeksi, kognisi, kecenderungan berperilaku. Respons tersebut mengarah pada hal positif-negatif, tingkat perasaan positif-negatif, dan dan intensitas komitmen individu atas posisi tertentu. Komponenkomponen afeksi sikap misalnya ketakutan, senang, simpati, benci, dan pernyataan setuju-tidak setuju. Menurut Bednar \& Levie $^{24}$ sikap tidak secara langsung tampak melainkan suatu kondisi yang turut memberi kontribusi terhadap tindakan dan perilaku. Hal ini berarti setiap perilaku seseorang berkaitan dengan sikap yang melekat pada dirinya.

Selanjutnya $\operatorname{Bird}^{25}$ memaknai sikap sebagai sesuatu yang berhubungan dengan penyesuaian diri seseorang kepada aspek-

${ }^{24}$ A. Bednar. \& W. H. Levie, "Attitude Change Principles", dalam M. Fleming \& W. H. Levie (eds.), Instructional Message Design: Principles from the Behavioral and Cognitive Sciences (Englewood Cliffs, New Jersey: Educational Technology Publications), 283-304.

${ }^{25}$ C. Bird, Social Psychology (New York: Appleton Century Co., 1967), 143-4. 
aspek lingkungan sekitar yang dipilih atau tindakan-tindakannya sendiri. Lebih luas lagi, sikap dapat dimaknai sebagai predisposisi (kecenderungan jiwa) atau orientasi kepada suatu masalah. Dengan demikian, sikap menjadi suatu kekuatan jiwa yang mendorong seseorang untuk berperilaku yang ditujukan kearah suatu objek tertentu.

Beberapa pendapat di atas diperkuat Gagne ${ }^{26}$ yang menyatakan sikap sebagai keadaan internal (internal state) yang mempengaruhi pilihan tindakan individu terhadap objek, pribadi, dan peristiwa. Keadaan internal dimaksud berupa keyakinan yang diperoleh dari proses akomodasi dan asimilasi pengetahuan yang didapatkan. Hal ini sejalan dengan pendapat Azwar ${ }^{27}$ bahwa sikap terhadap perilaku tertentu dipengaruhi oleh keyakinan mengenai perilaku normatif yang membentuk norma subjektif dalam diri individu. Keyakinan diri inilah yang mempengaruhi respon pribadi terhadap objek dan perilaku tertentu, misalnya jika diyakini membicarakan kejelekan orang lain sebagai perilaku tidak terpuji, maka ada kecenderungan dalam diri individu untuk tidak melakukan perbuatan tidak terpuji tersebut. Demikian halnya seseorang jika meyakini tolong-menolong itu baik, maka akan timbul respon positif terhadap orang yang ringan tangan.

Sikap pribadi seseorang yang berjiwa sosial-religius berkembang dalam pola hidup yang menghubungkan antara dirinya dengan Allah SWT. (

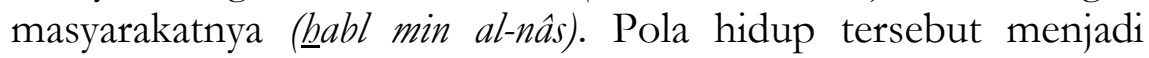
kerangka dasar sikap dan pandangan yang selalu berkembang secara harmonis. Pemerolehan kerangka dasar tersebut dapat dilakukan melalui proses pembelajaran sebagaimana dinyatakan

26R. M. Gagne \& J. B. Leslie, Principles of Instructional Design (New York: Holt, Rinehart, and Winston, Inc., 1974), 64.

${ }^{27}$ S. Azwar, Sikap Manusia: Teori dan Pengukurannya (Yogyakarta: Pustaka Pelajar, 2005), 12. 
Gerungan $^{28}$ bahwa sikap dapat ditumbuh kembangkan melalui proses pembelajaran. Sikap tidak berdiri sendiri melainkan berhubungan dengan aspek motivasi dan perasaan. Dengan demikian, pembelajaran akhlak mulia di sekolah dapat menumbuhkan sikap positif yang mengarah pada pembentukan akhlak mulia siswa.

\section{Nilai (Value)}

Nilai adalah konsepsi keinginan yang seharusnya diinginkan (conception of the desirable what ought to desired) terhadap sesuatu yang mempengaruhi pemilihan perilaku. ${ }^{29}$ Konsep nilai ini mengarah pada keyakinan yang sebenarnya berbeda dengan ketertarikan (interest). Hal ini senada dengan pendapat Rokeach ${ }^{30}$ yang menyatakan nilai sebagai keyakinan untuk melakukan sesuatu terkait dengan pembentukan keberadaan. Kedua pendapat di atas memberi penekanan pada keyakinan atas suatu nilai seperti halnya pernyataan Allport sebagaimana dikutip Mulyana ${ }^{31}$ bahwa nilai itu sebagai keyakinan yang mengarahkan seseorang bertindak atas dasar pilihannya. Keyakinan tersebut ditempatkan sebagai wilayah psikologis yang lebih tinggi dari wilayah lainnya seperti hasrat, motif, sikap, keinginan, dan kebutuhan.

Nilai sebagaimana dinyatakan Mulyana ${ }^{32}$ pada umumnya mencakup tiga ranah, yakni nilai intelektual (benar-salah), nilai estetika (indah-tidak indah), dan nilai etika (baik-buruk). Nilai dipandang abstrak tetapi dirasakan dalam diri seseorang sebagai

${ }^{28}$ W. A. Gerungan, Psikologi Sosial (Bandung: Refika Aditama, 2000), 33.

29J. W. Getzels, "The Problem of Interest: A Reconsideration", dalam Reading: Seventy-five Years of Progress. Supplementary Education Monographs, ed. H.A. Robinson (1966), 97-106.

${ }^{30} \mathrm{M}$. Rokeach, The Nature of Human Values (New York: Free Press, 1973), 25.

${ }^{31}$ R. Mulyana, Mengartikulasikan Pendidikan Nilai (Bandung: Alfabeta, 2004), 9.

32Ibid., 17-23. 
pendorong dan prinsip hidup. Oleh karena itu, nilai menempati posisi penting dalam kehidupan seseorang hingga pada tingkatan ketika seseorang lebih baik mengorbankan hidupnya ketimbang mengorbankan nilai. Nilai yang abstrak itu dapat diidentifikasi melalui kecenderungan pola pikir, pola sikap, dan perilaku yang berarti akhlak seseorang dipengaruhi oleh nilai-nilai yang diyakininya.

Posisi nilai dalam etika berlangsung sejak munculnya kehendak sampai pada lahirnya perbuatan yang bernilai baik buruk. Hal ini berarti nilai etika dilibatkan saat seseorang mulai berkehendak melakukan sesuatu sampai ia memiliki kebiasaan yang dapat diamati. Kehendak dan kebiasaan yang diberi label baik-buruk menandakan nilai dilibatkan dalam proses penilaian secara psikologis. Ketika etika memutuskan baik-buruk terhadap kebiasaan seseorang, maka nilai diwakili oleh kaidah-kaidah normatif aturan agama maupun kebiasaan yang berlaku di masyarakat. Dengan demikian menjadi jelas bahwa nilai dalam etika menempati dua posisi, yakni nilai sebagai keyakinan yang lahir melalui proses psikologis dan nilai sebagai ukuran yang merujuk pada kaidah normatif agama dan tata aturan kehidupan sosial.

Nilai dalam ilmu-ilmu behavioral lebih mempertimbangkan pentingnya nilai-nilai perilaku. Nilai-nilai tersebut merupakan petunjuk yang terinternalisasi dalam ekspresi perilaku yang ditampilkan seseorang. Nilai etika (penilaian baik-buruk) suatu perbuatan dapat bersumber dari pikiran manusia dan bersumber dari wahyu. Sumber pertama mensifatkan baik buruknya perilaku berdasarkan adat istiadat dan perilaku etis, sedangkan sumber kedua mensifatkan perilaku (akhlak) pada perintah dan larangan yang terdapat dalam wahyu al-Qur'an dan Hadis sebagai sumber kebenaran tertinggi. ${ }^{33}$

${ }^{3}$ Ibid., 21-3. 
Aktualisasi nilai ke dalam akhlak terpancar dari konsepsi dan perseptual seseorang tentang kehidupan dalam relasinya dengan Ilahi maupun sesama, dan nilai tersebut dapat berupa aqîdah islâmiyah (keyakinan terhadap kebenaran ajaran agama Islam). Akidah menjadi sumber kekuatan batin bagi setiap orang sehingga seseorang yang berpegang teguh padanya akan mendapatkan ketenteraman batin, sementara yang meninggalkan akan mengalami keresahan dalam batinnya. Oleh karena itu, nilai-nilai akidah yang benar akan merefleksikan falsafah hidup dan akhlak mulia berdasarkan tuntunan agama, sebaliknya dengan akidah yang lemah akan terefleksi pandangan hidup dan akhlak tidak terpuji. Akhlak mulia dan tercela merupakan dua kutub akhlak berlawanan yang terpancar dari sistem nilai yang berbeda, dan keduanya menentukan kualitas akhlak seseorang. Seseorang yang memiliki nilai-nilai akidah kokoh akan melahirkan individu yang saleh berakhlak mulia, sebaliknya seseorang yang memiliki nilai-nilai akidah yang rapuh cenderung berperilaku tidak terpuji dalam kehidupannya.

Pembentukan nilai-nilai akhlak itu bergantung pada refleksi diri mengenai kehidupan yang benar, eksistensi manusia sebagai hamba Allah, perbuatan dalam kaitannya dengan pahala dan dosa, hubungan kemasyarakatan dan sebagainya. Al-Qur'an dan hadis dalam hal ini banyak mengungkap idealitas perbuatan orang-orang beriman dan bertakwa, misalnya tersebut dalam surah al-Mukminûn (6):1-9 yang menegaskan tentang bagaimana seharusnya perilaku orang beriman.

Nilai-nilai akidah di atas menyebabkan orang-orang beriman mendasarkan kehidupannya pada tujuan yang benar sesuai syari'at Islam. Tujuan hidup manusia di dunia ini dalam kerangka pengabdian kepada Allah swt. sehingga setiap perilaku dan tindakannya senantiasa dimaksudkan untuk mendapatkan keridhaan-Nya. Nilai-nilai akidah ini memancarkan nilai-nilai yang murni dalam jiwa orang-orang beriman, nilai-nilai ikhlas atas segala amalnya. Perilaku orang-orang beriman dan bertakwa 
kepada Ilahi didasarkan pada nilai-nilai akidah yang benar, begitu juga akhlaknya terhadap sesama manusia dan lingkungannya.

Nilai-nilai yang dijadikan dasar penentuan baik-buruknya suatu akhlak dalam Islam berbeda dengan nilai-nilai Barat yang semata-mata bergantung kepada akal pikiran. Nilai-nilai Barat bersifat relatif yang keberlakuannya berbeda antar waktu dan wilayah. Nilai yang saat ini dipandang baik belum tentu baik di masa mendatang, demikian halnya baik untuk masyarakat tertentu belum tentu baik untuk masyarakat lainnya. Dasar yang menjadi rujukan nilai-nilai akhlak mulia dalam Islam adalah bersumber dari al-Qur'an, hadis, dan akal sehat.

Nilai-nilai sebagaimana diuraikan di atas menurut Kniker ${ }^{34}$ tidak dapat dipisahkan dari pendidikan. Nilai ditempatkan sebagai inti dari proses dan tujuan pembelajaran. Oleh karena itu dalam pengembangan strategi belajar nilai menurutnya selalu menampilkan tahapan penyadaran nilai, yakni identifikasi nilai yang menjadi target pembelajaran, kegiatan pembelajaran yang diarahkan pada penyadaran nilai, penggunaan media dan pengayaan strategi penyadaran nilai, dan penilaian kemajuan belajar. Hal ini berarti nilai dapat dipelajari dan ditumbuhkan melalui pembelajaran.

Selanjunya, akhlak mulia dalam wujud perilaku (behaviour) dapat dikategorikan ke dalam domain konatif. Perilaku akhlaki berdasarkan konsepsi moral dinamakan moral action. ${ }^{35}$ Menurut

${ }^{34}$ C. R. Kniker, You and Value Education (Ohio: Charless E. Mrrill Publishing Company, 1977), 41.

${ }^{35}$ Lihat, W. P. Derriberry \& S. J. Thomas, Moral Judgment, "Self Understanding and Moral Action: The Role of Multiple Construct", dalam ProQuest Education Journal, 2005, (52). 1; Ji Peter et.al., "A Measurement Model of Student Character as Described by the Positive Action Program", dalam Journal of Research in Character Education, 2004, (3), 2; Hendrix W. H. et.al., "Multimethod Approach for Measuring Change in Character", dalam Journal of Research in Character Education, 2004, (2), 1, 60; A. Rudd \& S. Stoll, "Measuring Student's Character in Secondary Education: The Development of principled Thinking Inventory", dalam Journal of Research in Character 
Derryberry, tindakan moral merupakan kumpulan sifat-sifat yang dipengaruhi oleh berbagai aspek. Dimensi perilaku akhlak mulia bila merujuk pada pendapat di atas berarti kemampuan seseorang untuk berperilaku terpuji secara nyata dalam kehidupannya. Perilaku ini merupakan manifestasi dari seperangkat karakteristik afektif termasuk kehendak yang dimiliki. Selain itu perilaku didasari oleh kekuatan dalam diri seseorang untuk melakukan sesuatu yang dipikirkan untuk selanjutnya dibiasakan dalam berperilaku. Berdasarkan dimensidimensi akhlak mulia yang perlu untuk dinilai selanjutnya dapat digambarkan sebagai berikut:

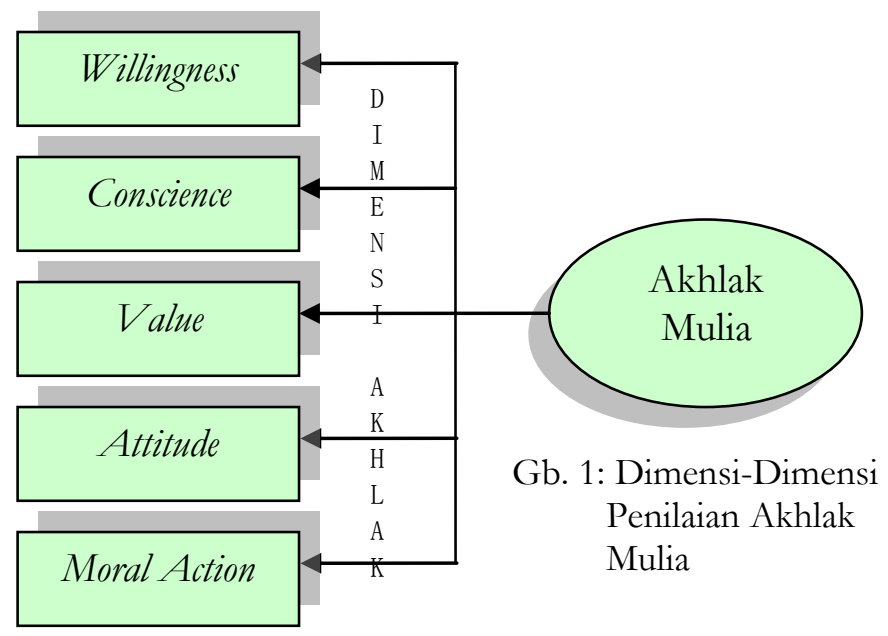

\section{Model dan Strategi Penilaian Akhlak Mulia}

Penilaian merupakan proses pengumpulan informasi yang digunakan untuk membuat suatu keputusan yang bersifat akuntabel. ${ }^{36}$ Penilaian dalam pembelajaran menurut Patrick

Education, 2004, (2), 2, 156; T. Lickona, Education for Character: How Our Schools Can Teach Respect and Responsibility (New York: Bantam Books, 1991), 52-62.

36L. W. Anderson, Classroom Assessment: Enhanching the Quality of Teacher Decision Making (London: Lawrence Erlbaum Associates Publisher, 2003), xi; 
dapat menjangkau aspek pemahaman, sikap, dan keterampilan peserta didik. Dalam konteks ini, penilaian diarahkan pada pengumpulan informasi mengenai akhlak peserta didik baik dalam dimensi karakteristik afektif maupun perilaku akhlaki (moral action).

Penilaian akhlak mulia dalam konteks pembelajaran berguna untuk membantu guru maupun peserta didik dalam menetapkan tahapan-tahapan pembelajaran akhlak yang seharusnya dicapai dan mengidentifikasi kekuatan serta kelemahan yang dimiliki masing-masing. Ditegaskan Weeden, ${ }^{37}$ bahwa penilaian itu terletak pada inti proses yang dapat menghasilkan kerangka pembuatan tujuan pendidikan dan kemajuan yang dicapai peserta didik. Penilaian dapat menjadi dasar perencanaan pada tahapan berikutnya sesuai kebutuhan peserta didik. Penilaian menjadi bagian integral proses pendidikan yang secara terus menerus menyediakan umpan balik dan informasi sehingga penilaian perlu disatukan secara sistematis ke dalam praktekpraktek pembelajaran. Secara spesifik penilaian akhlak mulia berguna bagi guru, sekolah, orang tua, dan peserta didik itu sendiri mengenai kualitas akhlaknya sekaligus dapat dijadikan acuan untuk melakukan pembinaan akhlak selanjutnya.

Penilaian akhlak mulia sebagai hasil dari pembelajaran melibatkan berbagai kegiatan meliputi pengamatan, pengumpulan informasi, pencatatan, penggambaran, pembuatan skor, dan melakukan interpretasi. Penilaian dapat melibatkan peserta didik karena pelibatan mereka sebagaimana dinyatakan Johnson \& Johnson ${ }^{38}$ dapat meningkatkan kualitas keputusan, meningkatkan komitmen untuk menerapkan asesmen secara

lihat juga, J. S. Stark \& A. Thomas (eds.), Assessment and Program Evaluation (Colifornia: Simon \& Schuter Custom Publishing, 1994), 3.

${ }^{37}$ P. Weeden. J. Winer \& P. Broadfoot, Assessment: What's in it for School? (New York: Routledge Falmer, 2002), 13.

${ }^{38} \mathrm{D}$. W. Johnson \& R. T. Johnson, Meaningful Assessment: A Manageble and Cooperative Process (Boston: Allyn \& Bacon, 2002), 4-5. 
berkualitas, mengurangi resistensi siswa terhadap umpan balik, meningkatkan capaian prestasi, menjadikan dirinya lebih termotivasi dalam belajar, dan pelibatan siswa cenderung meningkatkan penilaian diri.

Penilaian akhlak mulia dapat menerapkan model penilaian terpadu self dan peer assessment dengan melibatkan peserta didik secara inter dan intra individu. Self-assessment (penilaian diri sendiri) merupakan salah satu model penilaian untuk menilai kemampuan peserta didik oleh dirinya sendiri. Self-assessment umumnya digunakan untuk penilaian formatif dengan tujuan agar peserta didik dapat merefleksikan proses dan hasil belajarnya. ${ }^{39}$ Untuk pembelajaran yang berorientasi pada pembinaan akhlak mulia berarti peserta didik melakukan penilaian kualitas akhlak diri sendiri pada dimensi afektif dan perilaku akhlaki. Penerapan self-assessment pembelajaran tidak berarti peserta didik secara mandiri menilai akhlaknya melainkan diperlukan sharing dengan guru terkait dengan penentuan akhlak yang dinilai dan instrumen yang digunakan. Dalam hal ini, guru menyediakan instrumen penilaian yang akan dipergunakan untuk menilai dirinya sendiri. Penerapan self-assessment didasarkan pada argumentasi bahwa akhlak pada domain afektif bersifat personal sehingga diri peserta didik yang lebih mengetahui dan dapat menilainya.

Self-assessment memiliki esensi bagi siswa maupun guru dalam proses pembelajaran. Esensi model penilaian ini bagi peserta didik diantaranya dapat menumbuhkan tanggung jawab pada diri yang bersangkutan, memunculkan rasa percaya diri, keterlibatan secara aktif dalam proses penilaian, peserta menjadi lebih independen dalam belajar selain dapat meningkatkan motivasinya. Model penilaian ini juga dapat meningkatkan harga

${ }^{39}$ D. Sluijsmans, F. Dochy \& G. Moekerke, "Creating a Learning Environment by Using Self, Peer, and Co-Assessment", 1998. http://.extranet.ou.nl/inter-studie-alg-o31411/Symposium3/ materiaal/ bronnenmateriaal/Sluijmansea.pdf. 
diri dan mengembangkan semangat untuk melakukan refleksi diri. Selanjutnya, esensi bagi guru yakni terwujudnya pembagian tanggung jawab dari guru kepada peserta didik, tujuan pembelajaran lebih efisien dicapai, dan pemberian umpan balik membantu guru dalam mengidentifikasi kemajuan yang dicapai siswa.

Selanjutnya peer-assessment digambarkan sebagai kegiatan penilaian yang melibatkan antar peserta didik sekaligus memberikan umpan balik yang bersifat konstruktif. Sebagaimana dinyatakan Sluijsmans ${ }^{40}$ bahwa peer-assessment adalah suatu proses penilaian diberikan oleh teman sejawat dalam suatu kelompok. Dalam konteks ini peserta didik menilai akhlak teman sejawatnya di kelas yang terbatas jumlahnya (masing-masing menilai sekitar 3-4 orang temannya).

Penilaian model ini dilakukan peserta didik terbatas pada teman-teman belajar di dalam kelompoknya dengan mengacu pada kriteria yang telah dibuat/disepakati bersama guru. Guru perlu menentukan aspek-aspek akhlak yang dinilai sekaligus membuat kriterianya untuk selanjutnya dipergunakan oleh peserta didik untuk menilai teman-temannya. Penilaian diarahkan pada akhlak pada dimensi perilaku (moral action) karena dimensi ini dapat diamati oleh siswa satu sama lain di lingkungan sekolah. Penilaian akhlak dengan model ini didasarkan pada argumentasi keterbatasan guru dalam melakukan pengamatan atas perilaku peserta didik di sekolah yang jumlahnya sangat banyak.

Penilaian sejawat menjadi model penilaian interaktif yang dapat meningkatkan refleksi atas akhlak pada diri peserta didik. Model asesmen ini mengalihkan penilaian yang semula berpusat pada guru (instructor-centered) menjadi penilaian berpusat pada peserta didik (student-centered). Dikatakan berpusat pada peserta didik karena yang bersangkutan diperankan secara aktif untuk

\section{${ }^{40}$ Ibid.}


menilai akhlak teman-temannya. Hal ini berbeda dengan model asesmen tradisional yang lebih mengandalkan guru sebagai penilai satu-satunya.

Penilaian sejawat dalam proses pembelajaran menurut Noonan \& Duncan dapat digunakan untuk penilaian formatif, bahkan sumatif. Model penilaian ini tidak secara normal dapat digunakan secara tersendiri untuk penilaian sumatif sehingga perlu digabung dengan penilaian dari guru sehingga terjadi triangulasi. ${ }^{41}$ Penerapan penilaian akhlak mulia dengan memperhatikan keterpaduan tersebut menempatkan peserta didik sebagai subjek yang aktif partisipatif, pro-aktif, bertanggung jawab, reflektif, dan kolaboratif dalam proses pembelajaran.

Keterpaduan self dan peer-assessment sebagai model alternatif penilaian akhlak mulia dapat ditampilkan pada gambar berikut:

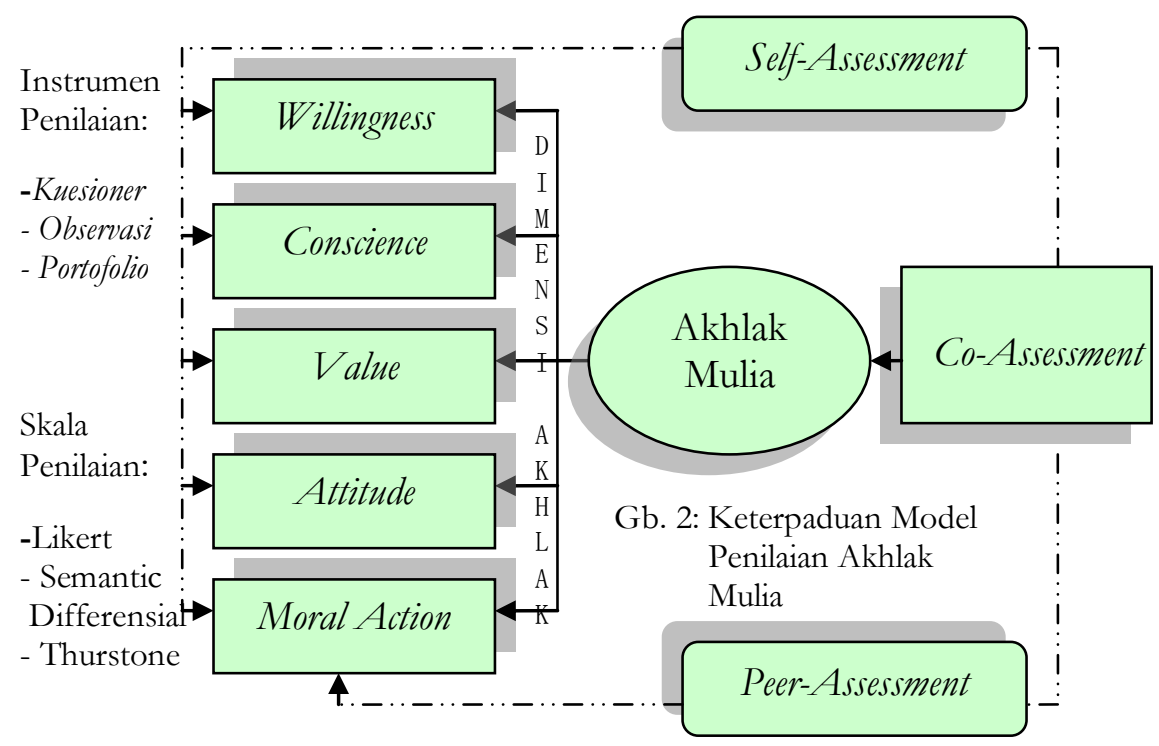

${ }^{41}$ B. Noonan \& C. R. Duncan, "Peer and Self-Assessment in High Schools: Practical Assessment, Research, and Evaluation", dalam A PeerReviewed Electronic Journal (10), 17. 
Penilaian akhlak mulia dapat menggunakan instrumen penilaian dalam bentuk kuesioner, observasi maupun portofolio. Instrumen tersebut di antaranya dapat menggunakan skala likert, semantic differensial dan skala thurstone selama relevan dengan dimensi-dimensi yang dinilai. Dimensi-dimensi akhlak mulia penilaiannya merujuk pada karakteristiknya masing-masing. Kehendak (willingness) dalam akhlak dapat dinilai dari intensitasnya, sedangkan kata hati (conscience) didasarkan pada refleksi diri khususnya menyangkut perasaan ketika melakukan suatu perbuatan. Penilaian sikap (attitude) ukurannya antara lain dinyatakan dengan ketertarikan seseorang untuk melakukan sesuatu ataupun pernyataan setuju-tidak setuju terhadap suatu perbuatan, sementara nilai (value) dinyatakan dengan pentingtidaknya suatu perbuatan dilakukan untuk mewujudkan perilaku terpuji. Selanjutnya perilaku (moral action) penilaiannya didasarkan pada intensitas suatu perbuatan secara nyata dilakukan.

\section{Catatan Akhir}

Akhlak mulia menjadi modal esensial bagi kehidupan bermasyarakat sehingga semua pihak menganggap pentingnya akhlak tersebut. Intensitas pembinaan akhlak mulia perlu dilakukan kepada semua lapisan masyarakat terutama para peserta didik, karena berakhlak mulia menjadi barometer kualitas diri seseorang baik dalam konteks hubungan vertikal dengan Ilahi maupun hubungan horisontal dengan sesama manusia. Menentukan kualitas akhlak mulia seseorang tidak dapat dilakukan sepintas lalu, tetapi dalam hal ini memerlukan penilaian secara komprehensif yang dapat menjangkau dimensi akhlak batiniyah dan labiriyah (perilaku akhlaki). Penilaian dengan menetapkan dimensi kehendak, kata hati, nilai-nilai, sikap dan perilaku keseharian dengan memadukan keterlibatan peserta didik secara inter dan intra individu diharapkan dapat menjadi model alternatif untuk penilaian akhlak mulia. 


\section{Daftar Pustaka}

A. Bednar. \& W. H. Levie, "Attitude Change Principles", dalam Instructional Message Design: Principles from the Behavioral and Cognitive Sciences, ed. M. Fleming \& W. H. Levie (Englewood Cliffs, New Jersey: Educational Technology Publications), 283-304.

A. F. Al-Ahwani, Al-Tarbiyyah fî al-Islâm (Kairo: Dâr Mâ'arif, t.t.). A. Rudd \& S. Stoll, "Measuring Student's Character in Secondary Education: The Development of Principle Thinking Inventory", dalam Journal of Research in Character Education, 2004, (2), 2, 156.

Aep Saefudin, "Akhlak dalam Perspektif Wacana Pemikir Muslim", dalam Jurnal Ta'dib, (2), 1, 2002, 70.

Ahmad Amîn, Etika (Ilmu Akblak) (Jakarta: Bulan Bintang, 1995).

Misriyyah, 1974).

Kitâb al-Akblâq (Kairo: Dâr al-Kutub al-

Al-Ghazâlî, Al-Arbaîn fî̀ Ushûl al-Dîn (Kairo: Maktabah al-Jindi, t.t.). , I hyyâ' 'Ulûm al-Dîn, Jilid III (Kairo: al-Masyhad alHusayn, t.t.).

Asmaran As, Pengantar Studi Akblake (Jakarta: Rajawali, 2002).

B. F. Skinner, About Behaviorism (New York: Vintage Books, 1976).

B. Noonan \& C. R. Duncan, "Peer and Self-Assessment in High Schools: Practical Assessment, Research, and Evaluation", dalam A Peer-Reviewed Electronic Journal, (10), 17.

B. Umary, Materi akblake (Solo: Ramadhani, 1993).

C. Bird, Social Psychology (New York: Appleton Century Co., 1967).

C. R. Kniker, You and Value Education (Ohio: Charless E. Mrrill Publishing Company, 1977). 
D. Sluijsmans, F. Dochy \& G. Moekerke, "Creating a Learning Environment by Using Self, Peer, and Co-Assessment", 1998. bttp:/ / extranet.ou.nl/inter-studie-alg-031411/Symposium3 / materiaal/ bronnenmateriaal/ Sluijmansea.pdf.

D. W. Johnson \& R. T. Johnson, Meaningful Assessment: A Manageble and Cooperative Process (Boston: Allyn \& Bacon, 2002).

Djemari Mardapi, Pengembangan Instrument Penelitian Pendidikan (Yogyakarta: Pascasarjana UNY, 2005).

Gable R. K., Instrument Development in the Affective Domain (Boston: Kliwer Nijhoff Publishing, 1986).

Hendrix W. H. et.al., "Multimethod Approach for Measuring Change in Character", dalam Journal of Research in Character Education, 2004, (2), 1, 60.

Ibrahîm Anîs, Al-Mu'jam al-W asîth (Mesir: Dâr Mâ'arif, 1972).

J. S. Stark. \& A. Thomas (eds.), Assessment and Program Evaluation (Colifornia: Simon \& Schuter Custom Publishing, 1994).

J. W. Getzels, "The Problem of Interest: A Reconsideration", Reading: Seventy-five Years of Progress. Supplementary Education Monographs, ed. H. A. Robinson (1966), 97-106.

Ji Peter et.al., "A Measurement Model of Student Character as Described by the Positive Action Program", dalam Journal of Research in Character Education, 2004, (3), 2.

L. W. Anderson, Classroom Assessment: Enhanching the Quality of Teacher Decision Making (London: Lawrence Erlbaum Associates Publisher, 2003). , Assessing Affective Characteristics in the Schools (Boston: Allyn \& Bacon, Inc. 1981).

M. J. al-Qâsimi, Mau'izab al- Mu'minîn, Jilid II (Kairo: Dâr al'Usûr li al-Tabha' wa al-Nasyr, 1969).

M. Rokeach, The Nature of Human Values (New York: Free Press, 1973). 
P. Black \& D. William, "Inside the Black Box: Raising Standards Through Classroom Assessment", dalam Phi Delta Kappa, 80 (2), 1998, 139-148.

P. Weeden, J. Winer \& P. Broadfoot, Assessment: What's in it for School? (New York: Routledge Falmer, 2002).

R. M. Gagne \& J. B. Leslie Principles of Instructional Design (New York: Holt, Rinehart, and Winston, Inc., 1974).

R. Mulyana, Mengartikulasikan Pendidikan Nilai (Bandung: Alfabeta, 2004).

S. Azwar, Sikap Manusia: Teori dan Pengukurannya (Yogyakarta: Pustaka Pelajar, 2005).

S. Hampshire, Freedom of Individual (New York: Harper, 1966), 16.

T. Lickona, Education for Character: How Our Schools Can Teach Respect and Responsibility (New York: Bantam Books, 1991).

W. A. Gerungan, Psikologi Sosial (Bandung: Refika Aditama, 2000).

W. P. Derriberry \& S. J. Thomas, Moral Judgment, "Self Understanding and Moral Action: The Role of Multiple Construct", dalam ProQuest Education Journal, 2005, (52). 1.

Zulkabir dkk., Islam Konseptual dan Kontekstual (Bandung: Itqan, 1993). 